Indonesian Journal of EFL and Linguistics

Vol. 6 No. 1, 2021

eISSN: 2503-4197, pISSN: 2527-5070

www. indonesian-efl-journal.org

doi: http://dx.doi.org/10.21462/ijefl.v6i1.353

\title{
Linguistic Purpose and Historical Implications of Malapropism and Code-Switching in the Philippines
}

\author{
Michael L. Estremera \\ ${ }^{a}$ Department of Education, Tugos Elementary School \\ ${ }^{b}$ Sorsogon State College (SSC) \\ Sorsogon City 4700, Philippines \\ e-mail: michael.estremera@deped.gov.ph
}

\begin{abstract}
:
The present article underpins the affirmation that colonization does have historical, linguistic, and cultural impact. Specifically, this paper explores the social malapropism and code-switching as trails of colonization dented by the American and Spanish regimes in the Philippines. The author concludes that malapropism occurs coupled with the code-switching linguistic phenomenon. Most of the malapropism episodes transpired is a prelude to shifting from one language to another. These occurrences have veiled implications and purposes which are established by the semantic features of the discourses. Collectively, the linguistic influence handed down by the colonizers had been found to be the chief contributory factor to the preceding phenomena. Bilingualism or even multilingualism induces malapropism and code-switching occurrences inevitably. The incompetence in choosing appropriate words and the low cache of lexical terms slightly affects the preceding phenomena. Taking into account the outcomes and conclusion, teachers must be cognizant of these occurrences to be able to cope with these phenomena accordingly thereby convert such drawbacks to communication into rich opportunities for meaningful classroom tête-à-tête. To the extent that there is complete communication cycle in malapropism and code-switching discourses, these could be exploited as bridges to learn the L2. Since there has likewise been language assimilation in code-switching, such can be used as an opportunity to master the second language by guiding learners toward fluency and accuracy.
\end{abstract}

Indonesian Journal of EFL and Linguistics, 6(1), 2021 169 
Michael L. Estremera

Morphological and phonological awareness will symbiotically follow sooner through series of drills and philosophical practice of the language.

Keywords: code-switching, etymology, linguistic hegemony, multilingualism error theory, malapropism

\section{INTRODUCTION}

Malapropism is an inappropriate word used inadvertently in place of another word with a related sound. Malapropisms can be comical because they give rise to irrational speeches. For instance, the common phrase "for all intents and purposes" is frequently turned into the malapropism "for all intensives and purposes." This phrase is slightly irrational, though in this scenario it's not comical to the extent that it is so often said mistakenly (https://cutt.ly/6es5CJs). Conversely, in linguistics, code-switching or language alternation potentially transpire when a speaker substitutes between two or more languages, or language variations, in the context of a single conversation. Multilingual interlocutors of more than one language, at times use features of multiple languages when communicating with each other. Consequently, code-switching is the practice of more than one linguistic variability in a manner consistent with the syntax and phonology of each variety (https://cutt.ly/Hes6olH). In fact, Mukti Prabowo et. al. (2018) concluded that codeswitching as utilized in the General English classes is unavoidable. One paramount reason is the fact that the students are not that English proficient and lexical range are not that wide, so lecturers resort to code-switching to help their students understand materials and instruction better. There were three types of codeswitching used by the lecturer in this research, namely tag switching, intra-sentential and inter-sentential code-switching. However, this present research delved into code-switching as it occurred on social-media platforms and casual conversations. The interconnectedness of code-switching and malapropism occurrences had likewise been explored as there seems very few studies available highlighting the forgoing linguistic phenomena.

\section{LITERATURE REVIEW}

\subsection{Metaphysics of Malapropism and Code-switching}

There is much argument in the field of linguistics concerning the dissimilarity between code-switching and language transfer (Treffers, 2009). In effect, the concerns of the use of code-switching as a medium of instruction in the context of English as Foreign Language (EFL) classes may have been deliberated already for many years since code-switching is deemed the last recourse used in multilingual 
Asian such as Indonesia (Liu, 2010; Mujiono, Poedjosoedarmo, Subroto, \& Wiratno, 2013). In some circumstances, linguists denote to the benefits and disadvantages of language transfer as two separate phenomena, i.e., language transference and language interference, correspondingly (Brice, 2015). In such interpretations, these two kinds of language transfer, along with code-switching can, encompass what is known as cross-linguistic influence (Brice, 2015). To some degree, an instance of discourse error is called a malapropism when a word is produced which is irrational or ridiculous in context, yet similar in sound to what was intended (Fay, 1982). Malapropisms vary from other kinds of speaking or writing errors, such as eggcorns or spoonerisms, and from the unintentional or cautious production of newly made-up words (neologisms) Zwickky, 1982). For instance, it is not a malapropism to use obtuse [wide or dull] instead of acute [narrow or sharp]; it is undoubtedly deemed a malapropism to use obtuse [stupid or slow-witted] when one meansabstruse [esoteric or difficult to understand]. Malapropisms usually maintain the part of speech of the initially intended word. Similarly, substitutions tend to have the same number of syllables and the same metrical structure - the same form of stressed and unstressed syllables - as the envisioned word or phrase. If the stress pattern of the malapropism varies from the intended word, unstressed syllables could be deleted or inserted; stressed syllables and the collective rhythmic patterns are maintained (Sheridan, 2005). Moreover, malapropisms of course are so named from Mrs Malaprop (from the French mal à propos, or inappropriately), a character from Richard Sheridan's The Rivals, who was wont to use wrong words that occurred to sound like the ones she wanted to utter ("He is the very pine-apple of politeness!" -> pinnacle). Though it's regularly regarded as stemming from ignorance, especially when politicians are making these amusing gaffes, it's honestly common communication error that can transpire even if the speaker knows entirely the lexical definitions of the e words. In the same vein, we may unsurprisingly make other semantic speech mistakes such as anticipating what we mean to say in our heads... and puzzlingly replacing it with its opposite. We may also substitute the word with a related word ("Don't burn your fingers"/"Don't burn your toes") or in an even more perplexing use of another word that sounds like a related word (heritage/legacy -> heresy) (https://bit.ly/38jCnwk).

\subsection{Colonization and English Language}

Phillipson (1992) scrutinized the probable reasons linked to English as the world's most dominant language. He claimed that the spread of English was not unpremeditated but, in effect, carefully planned. In one of his books, he highlighted how cultural and commercial undertakings of the colonizers played a pivotal function in determining the cultural symbol (e.g. Indian culture). Conversely, Pennycook (1998) argues that the colonial discourse around English and English culture may have been exploited to substantiate colonial and imperial economic activities, but these conversations about superiority of the former and the inferiority of the latter are not ordinary reactions of the material domain. These could have been manifestations of cultural discourse itself. To supplement, Calvet (1987)

Indonesian Journal of EFL and Linguistics, 6(1), 2021 
recognized two contributory steps to linguistic colonization. In Vertical step is connected to the social spread of English language. The European language first spread into the upper classes of the colonized people. Horizontal step, conversely, has to do with the geographical spread of language. The colonial language is diffused from the capital to the small cities and from there, to the villages. The colonizers spend much effort mainly through the educational system, on instilling this asymmetrical social ideology in their social and linguistic practices. This has likewise been underpinned by Spencer (1985) who conjectured that the colonizers language became a necessity for all those who wished to advance socially and to participate in the colony's public sphere. This is true to the socially-upward people who quickly came to eschew the local languages and to favor the colonial language. The educated increasingly opted to raising their children in a colonial language rather than an African language. Moreover, colonization and slave trade also led to the creation of new languages. The most well-known and studied cases are the Creole languages that occurred in the European plantation societies around the world [Carrebean, America, and Australia]. Coming from the diverse social and linguistic backgrounds, their creators- such as African slaves and European indented laborers in the case of Pacific creoles (Mint \& Price, 1976 and 1992). Similarly, Holm (1989), Mufwene (2015), and Muhleisen (2010) hypothesized that due to their having emerged as a direct consequence of European slavery, their surface resemblance to the colonial language, and their encounter with populations of low reputation, Creole was held in contempt by the Europeans. They are mostly not recognized as languages in their own right but are held to be make-shift languages and flawed or corrupted versions of the colonial language.

\section{RESEARCH METHODOLOGY}

\subsection{Research Design}

To be able to capture the linguistic purpose and historical implications of codeswitching and malapropism in the Philippines speech community, the author deemed qualitative research design most appropriate. According to Hammarberg et. al. (2016), qualitative methods are designed to investigate about the experience, meaning and perspective, most often from the viewpoint of the participant. The gathered data are commonly not subject to exploiting any statistical tools. Qualitative research techniques comprise 'small-group discussions' for exploring beliefs, attitudes, and concepts of normative behavior; 'semi-structured interviews', to seek views on a focused topic or, with key informants, for background information or an institutional perspective; 'in-depth interviews' to comprehend a condition, experience, or event from a personal standpoint; and 'analysis of texts and documents', such as government reports, media articles, websites or diaries, to learn about distributed or private knowledge. 
Linguistic Purpose and Historical Implications of Malapropism and Code-Switching

\subsection{Participants}

Participants to this undertaking are purposively selected considering the occurrences of code-switching and malapropism on social media and casual conversations. These are the social media practitioners, teachers, and students. Palinkas et. al. (2013) accentuate that purposeful sampling is widely used in qualitative research for the identification and selection of information-rich cases related to the phenomenon of interest. Although there are several different purposeful sampling strategies, criterion sampling appears to be used most commonly in implementation research. However, combining sampling strategies may be more appropriate to the aims of implementation research and more consistent with recent developments in quantitative methods.

\subsection{Data Collection Techniques}

This study primarily exploited transcription and documentary analysis as main tool in data collection. It made use of textual analysis and recorded conversations to expound clearly the occurrences of malapropism and code-switching as transpired over social media platforms. In effect, document analysis is a methodical procedure for reviewing or evaluating documents-both printed and electronic (computerbased and Internet-transmitted) material. Like other analytical approaches in qualitative research, document analysis necessitates that data be scrutinized and inferred in order to elicit meaning, gain understanding, and develop empirical knowledge (Corbin \& Strauss, 2008).

\section{FINDINGS}

Malapropism and code-switching as trails of Spanish epoch and American regimes in the Philippines are confirmed by the preceding literatures and studies in the field of linguistics. For clarity of the foregoing linguistic phenomenon, the current author deems it appropriate to dichotomize and dissect accordingly the occurrences of malapropism and code switching and their concealed discourse implications and purposes. Dissecting the above linguistic occurrences will give rise to the etymology of Philippines rich linguistic diversity. Evident in table 1 is the occurrence of two linguistic phenomena called malapropism and code-switching committed by movie theater spectators. In Philippines context, these occurrences seem to go together. As interlocutors attempt to transfer from one code to another, error in pronunciation or choice of words is likely to happen. The spelling of the target word is also compromised; however, its semantics aspect has also been found successful as highlighted by the above table. In effect, the code [\#SM\&CS1] shows the very concrete example of the above claim. The speaker started with a native language [Ay] and immediately shifted to another language [Spanish] then to another language anew [English].

Indonesian Journal of EFL and Linguistics, 6(1), 2021 
Michael L. Estremera

Table 1: Social Malapropism \& Code Switching on Movie Theater by the Spectators

\begin{tabular}{|c|c|c|c|}
\hline CODE & DISCOURSE LINES & $\begin{array}{c}\text { PHILLIPPINES CONTEXT } \\
\text { ENGLISH } \\
\text { TRANSLATION }\end{array}$ & $\begin{array}{l}\text { LINGUISTIC } \\
\text { PURPOSE }\end{array}$ \\
\hline \#SM\&CS1 & $\begin{array}{l}\text { Ay! Que Corny!I dunno what } \\
\text { Rock sees in her. }\end{array}$ & $\begin{array}{l}\text { Oh! You're cheap! I don’t } \\
\text { know what Rock sees in her. }\end{array}$ & $\begin{array}{l}\text { to express } \\
\text { dismay/dislike }\end{array}$ \\
\hline \#SM\&CS2 & $\begin{array}{l}\text { It's a corny love story, when } \\
\text { you think about it. }\end{array}$ & $\begin{array}{l}\text { It's a cheap love story, when } \\
\text { you think about it. }\end{array}$ & $\begin{array}{l}\text { to extend } \\
\text { discouragement }\end{array}$ \\
\hline \#SM\&CS3 & $\begin{array}{l}\text { Ay! Puede ba, you have weird } \\
\text { taste! "She is really cara de } \\
\text { achay if you ask me". }\end{array}$ & $\begin{array}{l}\text { Hey! Excuse me!, you have } \\
\text { weird taste! "She looks like a } \\
\text { housemaid if you ask me". }\end{array}$ & $\begin{array}{l}\text { to insist and } \\
\text { discredit }\end{array}$ \\
\hline \#SM\&CS4 & $\begin{array}{l}\text { She looks like a cat aw-right, } \\
\text { she says with her thick, } \\
\text { singsong accent. }\end{array}$ & $\begin{array}{l}\text { She looks like a cat alright, she } \\
\text { says with her thick, singsong } \\
\text { accent. }\end{array}$ & $\begin{array}{l}\text { to dishonor by } \\
\text { associating } \\
\text { offensive words }\end{array}$ \\
\hline \#SM\&CS5 & $\begin{array}{l}\text { But if you ask me, prima, } \\
\text { Gloria Talbott looks like a } \\
\text { trapo. }\end{array}$ & $\begin{array}{l}\text { But if you ask me, cousin, } \\
\text { Gloria Talbott is comparable to } \\
\text { a dish rag. }\end{array}$ & $\begin{array}{l}\text { to express personal } \\
\text { opinion }\end{array}$ \\
\hline \#SM\&CS6 & $\begin{array}{l}\text { "Pobre Rock!" Every time he } \\
\text { has to kiss her- Pucha } \\
\text { shudders at the thought. }\end{array}$ & $\begin{array}{l}\text { "Poor Rock!" Every time he } \\
\text { has to kiss her - Pucha } \\
\text { shudders at the thought. }\end{array}$ & $\begin{array}{l}\text { to express mercy } \\
\text { and sympathy }\end{array}$ \\
\hline
\end{tabular}

Source: (Hagedorn, 1990)

However, as the speaker attempts to transcode from Spanish to English, he mispronounced or even misrepresented don't know from dunno. Although the speaker here committed an error, he was able to converse successfully and was actually understood by the receiver of the message. Semantically, both the speaker and the receiver were able to complete the process of communication as the implied meaning [to express dismay/dislike] was imbibed by the receiver. For the code [\#SM\&CS2], the speaker used a colloquial term [corny] instead of an accurate lexis [cheap] to mean discouragement. This informal word has indeed been widely accepted in the Philippines archipelago when conversing. It denotes something that is cheap, not practical, or of low quality material things. To supplement, the discourse line [Ay! Puede ba, you have weird taste! "She is really cara de achay if you ask me] coded as [\#SM\&CS3] reveals the lingering legacy of Spanish and American regimes in the Philippines. As noted, speaker here is showing his multilingual prowess by trying to use three languages [Filipino, Spanish, and English] in conversing with the receiver of the message. He started with his native language, transcode to Spanish, and then ended his line with English lexes with linguistic purposes of insisting and discrediting someone. For the coded conversation [\#SM\&CS4] malapropism has likewise been apparent to the extent that the English word alright was mistakenly used as aw-right. However, though phonologically an error was committed, the chief purpose of communicating still transpired, the receiver of the message figured-out that the speaker's purpose which 
is to dishonor by associating offensive words. For conversations [\#SM\&CS5 and \#SM\&CS6], the linguistic phenomenon common to colonized countries is also highlighted called code-switching. Scrutinizing fully the foregoing conversations would imply that these linguistics occurrences are closely associated to colonization. The colonized countries e.g. Philippines, attempt to use the languages which a purpose in mind. The errors committed are deemed trivial for the sake of extending and expressing ideas and opinions. To some extent, the legacy of the colonizers create a status symbol; hence, patronized and used by Filipino people in the case of the Philippines. Indeed, Spencer (1985) inferred that the colonizers language became a necessity for all those who wished to advance socially and to participate in the colony's public sphere. This is true to the socially-upward people who quickly came to eschew the local languages and to favor the colonial language. The educated increasingly opted to raising their children in a colonial language rather than an African language. Rafael (1993 and 1999) also discussed the interplay of lingua franca and the introduced language by the colonizers in the Philippines [ English and Spanish ] thru linguistic phenomena called malapropism and code-switching. The sociocultural impact was also tackled by highlighting the conversations of Filipino movie viewers watching American film. Noteworthy, however, in the article titled "Taglish, or the phantom power of the lingua franca" is the occurrence of word insertions from mother tongue to either Spanish or English language, vice versa, by the interlocutors [e.g. Ay puede ba, you have weird taste! She's really cara de achay if you ask me]. The above author also established the fact that mestizones as a colonial aftermath, has always been associated to the sources of power and an object of envy and perfection. This is confirmed at the outset of the article the two characters [ Rio and Pucha] made envious descriptions of the movie actresses they viewed.

Table 2: Code Switching on Movie Theater by the Actors

\begin{tabular}{|c|c|c|c|}
\hline CODE & DISCOURSE LINES & $\begin{array}{c}\text { PHILLIPPINES CONTEXT } \\
\text { ENGLISH } \\
\text { TRANSLATION } \\
\end{array}$ & $\begin{array}{l}\text { LINGUISTIC } \\
\text { PURPOSE }\end{array}$ \\
\hline \#SM\&CS7 & $\begin{array}{l}\text { Edith, ano ba ang } \\
\text { appointments ko for today? }\end{array}$ & $\begin{array}{l}\text { Edith, what are appointments } \\
\text { for today }\end{array}$ & $\begin{array}{l}\text { to ask, clarify and } \\
\text { confirm }\end{array}$ \\
\hline \#SM\&CS8 & $\begin{array}{l}\text { Mamayang five ho, kay Mr. } \\
\text { Santos. Yung dinner n'yo ho } \\
\text { at seven sa bahay ng brother } \\
\text { ninyo. }\end{array}$ & $\begin{array}{l}\text { Later at five o'clock, to Mr. } \\
\text { Santos. You have will have } \\
\text { dinner in your brother's } \\
\text { residence. }\end{array}$ & $\begin{array}{l}\text { to confirm and } \\
\text { give assurance }\end{array}$ \\
\hline \#SM\&CS9 & $\begin{array}{l}\text { At saka pumirma din sa } \\
\text { ganyang arrangement si Stella } \\
\text { bago sila ikinasal ni Robbie. }\end{array}$ & $\begin{array}{l}\text { Besides, Stella signed on that } \\
\text { arrangement before they were } \\
\text { wed with Robbie. }\end{array}$ & $\begin{array}{l}\text { to insist and } \\
\text { remind }\end{array}$ \\
\hline \#SM\&CS10 & $\begin{array}{l}\text { Bakit masyado kang nagiging } \\
\text { emotional pagdating sa } \\
\text { dokumentong ito? }\end{array}$ & $\begin{array}{l}\text { Why are you so emotional } \\
\text { regarding this document? }\end{array}$ & $\begin{array}{l}\text { to ask, clarify and } \\
\text { confirm }\end{array}$ \\
\hline \#SM\&CS11 & $\begin{array}{l}\text { Bert, let me handle this. Hija, } \\
\text { we are not questioning the }\end{array}$ & $\begin{array}{l}\text { Bert, let me handle this. Hija, } \\
\text { we are not questioning the love }\end{array}$ & $\begin{array}{l}\text { to support and } \\
\text { give opinion }\end{array}$ \\
\hline
\end{tabular}

Indonesian Journal of EFL and Linguistics, 6(1), 2021 


\begin{tabular}{ll}
$\begin{array}{l}\text { love you have for each other. I } \\
\text { think Phillip is a wonderful } \\
\text { guy. He's intelligent, he's } \\
\text { sensitive }\end{array}$ & $\begin{array}{l}\text { you have for each other. I think } \\
\text { Phillip is a wonderful guy. }\end{array}$ \\
$\begin{array}{l}\text { I'll make it easier for you. If } \\
\text { Phillip doesn't sign this } \\
\text { agreement, at magpapakasal, he's sensitive } \\
\text { \#SM\&CS12 } \\
\text { gagalitin mo. kami na ang }\end{array}$ & $\begin{array}{l}\text { I'll make it easier for you. If } \\
\text { Phillip doesn't sign this } \\
\text { agreement, and you insist to } \\
\text { marry him still, we'll surely get and give warning } \\
\text { mad. }\end{array}$ \\
\hline
\end{tabular}

Source: Taglish, or the phantom power of lingua franca by Vicente R. Rafael (p. 116-119)

In linguistics, code-switching or language alternation transpires when a speaker replaces between two or more languages, or language variations, in the context of a single tête-à-tête. Multilingual speakers of more than one language, at times use elements of multiple languages when communicating with each other. Accordingly, code-switching is the use of more than one linguistic variation in a manner consistent with the syntax and phonology of each variety (https://cutt.ly/Hes6olH). Hence, the foregoing table presents the occurrence of code switching committed by the actor interlocutors. Coded dialogues [\#SM\&CS7 and \#SM\&CS8] show parallelism as to linguistic purpose. Speakers here want to clarify and to give assurance by using two sets of languages [English and Filipino] common to both the speaker and the listener of the message. Also, in Philippines context, code-switching is also prevalent if speaker wishes to insist and to remind the audience of whatever is impending or happening within the vicinity. This is confirmed by the discourse line [At saka pumirma din sa ganyang arrangement si Stella bago sila ikinasal ni Robbie] coded as [\#SM\&CS9]. Additionally, a speaker also transcodes if he would like to support in conversation and/or give his stance in the long run, on certain issues while conversing [Bert, let me handle this. Hija, we are not questioning the love you have for each other. I think Phillip is a wonderful guy. He's intelligent, he's sensitive]. In this line, the speaker sent the message by utilizing the L2 [English] followed by Spanish word [Hija], and then back to the first code which he used from the very start of conversation. Nonetheless, for the discourse line [I'll make it easier for you. If Phillip doesn't sign this agreement, at magpapakasal parin kayo, kami na ang gagalitin mo.] coded as [\#SM\&CS12] confirm anew the fact that American colonization practically has had linguistic impact to the Philippines when conversing both in speech and in written form. 
Table 3: Social Malapropism on Comic Plays

\begin{tabular}{|c|c|c|c|}
\hline CODE & DISCOURSE LINES & $\begin{array}{c}\text { PHILLIPPINES CONTEXT } \\
\text { ENGLISH } \\
\text { TRANSLATION }\end{array}$ & $\begin{array}{l}\text { LINGUISTIC } \\
\text { PURPOSE }\end{array}$ \\
\hline \#SM\&CS7 & $\begin{array}{l}\text {...bes preng ko siya } \\
\text { siyempre... }\end{array}$ & $\begin{array}{l}\text {...he is my best friend that's } \\
\text { why... }\end{array}$ & to give assurance \\
\hline \#SM\&CS8 & ...wa-is lng ako kaya ganun... & ...I am just wise for such... & $\begin{array}{l}\text { to express } \\
\text { practicality }\end{array}$ \\
\hline \#SM\&CS9 & $\begin{array}{l}\text {...wajawang to know pare } \\
\text { ha?... }\end{array}$ & $\begin{array}{l}\text {... What do you want to know } \\
\text { buddy huh?... }\end{array}$ & to ask and inform \\
\hline \#SM\&CS10 & $\begin{array}{l}\text {...dasbitor kaya lng...ok sige } \\
\text { na nga... }\end{array}$ & $\begin{array}{l}\text {...That is better, but, ...ok I } \\
\text { agree... }\end{array}$ & to agree \\
\hline \#SM\&CS11 & $\begin{array}{l}\text {...mas ok ng maging jeprox } \\
\text { para in sa grupo... }\end{array}$ & $\begin{array}{l}\text {...Being hippie is ok to be with } \\
\text { the group's fashion... }\end{array}$ & $\begin{array}{l}\text { to express } \\
\text { practicality }\end{array}$ \\
\hline \#SM\&CS12 & $\begin{array}{l}\text {...haha..loko ka talaga....anong } \\
\text { say mo dun..ok ba?... }\end{array}$ & $\begin{array}{l}\text {...haha...you're such fool } \\
\text { buddy... What do you say to } \\
\text { that?...is it nice?... }\end{array}$ & to ask for opinion \\
\hline \#SM\&CS13 & $\begin{array}{l}\text {...we-no?!..wala kang } \\
\text { pakialam dun ok?.. }\end{array}$ & $\begin{array}{l}\text {...Oh, well, so what?...none of } \\
\text { your business ok?... }\end{array}$ & to insist \\
\hline
\end{tabular}

Source: (Marcelo, 1987)

Linguistic phenomenon termed as malapropism is an unfitting word used unintentionally in place of another word with a similar sound. Malapropisms can be funny-sounding since they give rise to illogical statements. For example, the common phrase "for all intents and purposes" is often turned into the malapropism "for all intensives and purposes." This phrase is slightly irrational, though in this case it's not funny at all because at times it is also said erroneously by some speakers (https://cutt.ly/6es5CJs). Table 3 confirms the fact that malapropism as an aftermath of colonization varies from country to country and race to race. However, despite the noted phonologic and morphologic error, the identity of the user of the language where malapropism happened still carries its linguistic identity. Semantically, speakers and receivers of information are still able to deduce between and beyond the lines of communication. The paramount purposes of conversation still transpired as highlighted by the preceding table of malapropism occurrence on comic plays. Coded discourse lines such as [\#SM\&CS7, \#SM\&CS8, \#SM\&CS9, \#SM\&CS10, \#SM\&CS11, \#SM\&CS12, and \#SM\&CS13] are a concrete example of malapropism due to American colonization. Filipinos during those times nativized or even invented a queer words or languages by combining the native language and the English language on comic plays. These comic plays are reading materials which depict Philippines' hot issues and concerns during those times. However, some patriotic persons denounce this linguistic phenomenon as it distorts the original word. However, if investigated carefully, the lexes form meaning and have concealed linguistic purposes. 
Table 4: Code-Switching on Broadcast Media

\begin{tabular}{|c|c|c|c|}
\hline CODE & DISCOURSE LINES & $\begin{array}{c}\text { PHILLIPPINES CONTEXT } \\
\text { ENGLISH } \\
\text { TRANSLATION }\end{array}$ & $\begin{array}{l}\text { LINGUISTIC } \\
\text { PURPOSE }\end{array}$ \\
\hline \#SM\&CS14 & $\begin{array}{l}\text { Si Bong Lopez will be giving us } \\
\text { the details of this activity that will } \\
\text { happen today urog nang gayo dara } \\
\text { kan RJE Production. }\end{array}$ & $\begin{array}{l}\text { Bong Lopez will be giving us the } \\
\text { details of this activity that will } \\
\text { happen today brought to us by the } \\
\text { RJE Production. }\end{array}$ & to notify \\
\hline \#SM\&CS15 & $\begin{array}{l}\text { Now, sisay naman ang } \\
\text { nakaantabay sa ciudad nin } \\
\text { Sorsogon...because an major } \\
\text { thoroughfares iyo po tabi...ang } \\
\text { magiging venue... }\end{array}$ & $\begin{array}{l}\text { Now, whoever is tuning in us in } \\
\text { the city of Sorsogon...because the } \\
\text { major thoroughfares will be the } \\
\text { venue. }\end{array}$ & $\begin{array}{l}\text { to clarify and } \\
\text { guide }\end{array}$ \\
\hline \#SM\&CS16 & $\begin{array}{l}\text { Ngonyan na aga... nuh...while we } \\
\text { will not be able to cover live...but } \\
\text { of course nakalibot po diyan an } \\
\text { ating mga reporters. }\end{array}$ & $\begin{array}{l}\text { This morning, nuh... while we } \\
\text { will not be able to cover live..but } \\
\text { of course reporters are at the } \\
\text { venue to monitor. }\end{array}$ & $\begin{array}{l}\text { to give } \\
\text { assurance }\end{array}$ \\
\hline \#SM\&CS17 & $\begin{array}{l}\text { Si Jerry Bigtas mga kababayan... } \\
\text { sigurado yadi ine sa contingent } \\
\text { kan Casiguran... }\end{array}$ & $\begin{array}{l}\text { Jerry will surely be joining in } \\
\text { Casiguran contingent. }\end{array}$ & $\begin{array}{l}\text { to express } \\
\text { certainty }\end{array}$ \\
\hline \#SM\&CS18 & $\begin{array}{l}\text { So...may possibility din that Mar } \\
\text { Romero will be in the delegation } \\
\text { of Pilar or Donsol area. }\end{array}$ & $\begin{array}{l}\text { So... there is also a possibility } \\
\text { that Mar Romero will be in the } \\
\text { delegation of Pilar or Donsol area. }\end{array}$ & to conclude \\
\hline \#SM\&CS19 & $\begin{array}{l}\text { Then, alas nuebe nin aga ngonyan, } \\
\text { iyo po an Historico de Culural } \\
\text { Parrade. }\end{array}$ & $\begin{array}{l}\text { Then, at nine o'clock will be } \\
\text { History of Cultural Parrade. }\end{array}$ & to supplement \\
\hline \#SM\&CS20 & $\begin{array}{l}\text { Buenas dias es todos mis amigos } \\
\text { es mis amigas, cumadres es } \\
\text { cumpadres ... senyores, senyoritas } \\
\text { de las familias... It's specially } \\
\text { working holiday nuh... for the } \\
\text { province of Sorsogon. } \\
\text { In celebration of our }\end{array}$ & $\begin{array}{l}\text { Good day to you everyone, my } \\
\text { friends, ladies, gentlemen, } \\
\text { buddies and the members of the } \\
\text { family. It's a specially working } \\
\text { holiday nuh... for the province of } \\
\text { Sorsogon. } \\
\text { In celebration of our }\end{array}$ & $\begin{array}{l}\text { to express } \\
\text { positivity and } \\
\text { to inform }\end{array}$ \\
\hline \#SM\&CS21 & $\begin{array}{l}\text { Kasanggayanhan Festival..iyo } \\
\text { man talaga an ano... } \\
\text { an...culminating activity... }\end{array}$ & $\begin{array}{l}\text { Kasanggayanhan Festival..this is } \\
\text { really the... the...culminating } \\
\text { activity... }\end{array}$ & to reminisce \\
\hline \#SM\&CS22 & $\begin{array}{l}\text { And then we have the Sorsogon } \\
\text { thanks giving day..and a mass in } \\
\text { celebration for the } 125^{\text {th }} \text { founding } \\
\text { anniversary... ine an } \\
\text { ahhh... activity natin... }\end{array}$ & $\begin{array}{l}\text { And then we have the Sorsogon } \\
\text { thanks giving day...and a mass in } \\
\text { celebration for the } 125^{\text {th }} \text { founding } \\
\text { anniversary... this is } \\
\text { the...ahhh..our activity... }\end{array}$ & to notify \\
\hline \#SM\&CS23 & $\begin{array}{l}\text { Okay?...that will be today..kaya } \\
\text { naka "Kasanggayan" } t \text {-shirt ako } \\
\text { ngayon...yang ang } t \text {-shirt ng } \\
\text { Sangguniang Panlalawigan }\end{array}$ & $\begin{array}{l}\text { Okay?...that will be today..that's } \\
\text { why I am wearing a "Prosperity" } \\
\text { t-shirt today...this is the t-shirt of } \\
\text { Provincial Board Members }\end{array}$ & $\begin{array}{l}\text { to express } \\
\text { jubilation }\end{array}$ \\
\hline \#SM\&CS24 & $\begin{array}{l}\text { So mga darling, mga sweetheart, } \\
\text { mga mahal, bago an gabos, sana }\end{array}$ & $\begin{array}{l}\text { At this point, honey, sweetheart, } \\
\text { love, before anything else, let us }\end{array}$ & $\begin{array}{l}\text { to spread } \\
\text { positive vibes }\end{array}$ \\
\hline
\end{tabular}


Linguistic Purpose and Historical Implications of Malapropism and Code-Switching

\begin{tabular}{|c|c|c|c|}
\hline & $\begin{array}{l}\text { giyahan kita sa aldaw ine...taw-an } \\
\text { kita ki maray na lawas asin salud. }\end{array}$ & $\begin{array}{l}\text { pray for a strong body anda good } \\
\text { health for all. }\end{array}$ & \\
\hline \#SM\&CS25 & $\begin{array}{l}\text { Oh huh...harayuon pa ine..this is } \\
\text { swimsuit competition ... }\end{array}$ & $\begin{array}{l}\text { Oh huh...this is still far...this is } \\
\text { swimsuit competition.. }\end{array}$ & to anticipate \\
\hline
\end{tabular}

Source: Padaba Radio Live Simulcast, October 17, 2019.

Broadcast media are undoubtedly powerful instrument of spreading the information regarding debatable issues and concerns. In fact, Taglish (combination of Tagalog and English language) became the preferred idiom of popular dissent especially in the period following the assassination of Benigno "Ninoy" Aquino (popular politician) in 1983 culminating in the People Power Revolt of 1986. Urban discourse critical of the Marcoses [Filipino Dictator President] took the form of puns, $j$ okes, and assorted wordplay on the regime's pronouncements and the names of its leaders (Rafael, 1986). Thus, to confirm whether such manifestations of code-switching have still prospered to the present date or not, table 4 below has been made intently for the purpose. It is noticeable that broadcast media still practice code-switching from mother tongue to national language and English, or Filipino and English language only with linguistic purposes in order to convey messages to the audience effectively. As a matter of fact, codes [\#SM\&CS14 and \#SM\&CS15] are meant to notify, clarify, and guide the listeners of the event that will happen within the speech community. Speaker started by using Filipino word [Si] and immediately shifted to English lexes [Bong Lopez will be giving us the details of this activity that will happen today] and ended his discourse through a known dialect to the radio hearers [ urog ng gayo]. To further establish the occurrence of code-switching, the discourse line [Ngonyan na aga... nuh...while we will not be able to cover live..but of course nakalibot po diyan an ating mga] involves the use of Bicol dialect (one of the Philippine languages) and English lexes with a conjunction, pronoun, modal, verb, and a noun; however, it ended with the use Bicol of dialects. This sudden shift from one language to another practically confirms that English as one of the legacies of American colonization is still embraced by the Filipinos in this modern and technological epoch. Moreover, the coded speech line as [\#SM\&CS20] also confirms that the Spanish colonization has also been successful of their mission to spread their language identity. The speaker threw some Spanish lexes [Buenas dias es todos mis amigos es mis amigas, cumadres es cumpadres ...senyores, senyoritas de las familias] in form of greetings and ended his line by using English words. In this line, the purpose of the speaker could probably be deduced from the cultural background of the Filipinos. In a nutshell, the preceding speech lines are designed to express positivity and to set the tone of the speaker. For the code [\#SM\&CS21], the speaker used English language and Bicol dialect to reminisce the scheduled events thereby informing the listeners of the nearing events. Linguistically, this odd combination of two languages may appear erroneous; but, in the context of the listeners and the speaker, they had been able to reach the common point of

Indonesian Journal of EFL and Linguistics, 6(1), 2021 
Michael L. Estremera

communication. This could be so due to familiarity of both the speaker and of the audiences of two or three set of languages.

Table 5: Malapropism during Casual Conversations by the Millennial High School Students

\begin{tabular}{|c|c|c|c|}
\hline CODE & DISCOURSE LINES & $\begin{array}{l}\text { PHILLIPPINES CONTEXT } \\
\text { ENGLISH TRANSLATION }\end{array}$ & $\begin{array}{l}\text { LINGUISTIC } \\
\text { PURPOSE }\end{array}$ \\
\hline \#SM\&CS26 & Bruh...let's trip & Let us go... brother & to order \\
\hline \#SM\&CS27 & $\begin{array}{l}\text { You are parking at the wrong } \\
\text { gate... hahaha..sabi ng friend } \\
\text { ko but actually it should be... }\end{array}$ & $\begin{array}{l}\text { You are barking at the wrong } \\
\text { tree... hahaha..my friend told } \\
\text { me... but actually it should } \\
\text { be... }\end{array}$ & to evoke argument \\
\hline \#SM\&CS28 & $\begin{array}{l}\text { Hoy..please pick up the paper } \\
\text { naman and fall it in the trash } \\
\text { can... }\end{array}$ & $\begin{array}{l}\text { Hey..please pick up the paper } \\
\text { and throw it in the trash can... }\end{array}$ & $\begin{array}{l}\text { to give a } \\
\text { command }\end{array}$ \\
\hline \#SM\&CS29 & $\begin{array}{l}\text { Sir... our principal is revolving } \\
\text { around the corridor now. }\end{array}$ & $\begin{array}{l}\text { Sir... our principal is walking } \\
\text { around the corridor now. }\end{array}$ & to notify and warn \\
\hline \#SM\&CS30 & $\begin{array}{l}\text { Hello... please open window- } \\
\text { let the airforce come in. }\end{array}$ & $\begin{array}{l}\text { Hello... please open } \\
\text { window_let the air come in. }\end{array}$ & $\begin{array}{l}\text { to request and } \\
\text { insist }\end{array}$ \\
\hline
\end{tabular}

Source 3: Cyril Victoria, IELTS Coach (October 17, 2019)

In the Philippines with very rich linguistic typologies, malapropism occurs inevitably coupled with code-switching as well. Offenders usually try to shift from one code to another, from native language to English language, in particular. They find difficulty thinking of the most appropriate word; hence, similarly-sounding words are usually substituted to complete the sentence and be able to send the message successfully. For instance, [Bruh...let's trip] translated into English as "Let's go brother", means that the speaker abbreviated the word brother for simply "bro". However, "bruh" and "bro" differ phonologically. The former lexis perhaps is influenced by mother tongue accent while the latter of course is more appropriate. In fact, the former has been widely used in the Bicol archipelago to address to someone [a close friend, male stranger, or more often than not, referring to a brother itself]. As for the words "trip" and "go" where the former was mistakenly used, denotes that the speaker associated the foregoing word to strolling which somehow is relevant to the word "go" semantically. Be that as it may, these barriers to communication were surpassed by the receiver of the message; hence, the purpose of communication was still achieved. In addition, the speech line [You are parking at the wrong gate...hahaha..sabi ng friend ko but actually it should be...] coded as [\#SM\&CS27] was inaccurately used instead of "You are barking at the wrong tree". The speaker here erroneously used the word "parking" instead of "barking" due perchance to phonological similarity of the words. Moreover, the word "gate" was likewise used in lieu of the most appropriate word "tree" to complete the message. Though the words "gate" and "tree" are not related in meaning, the speaker perhaps opted to use the wrong word to associate to the word "parking". Figuratively, the implied meaning could not be understood by the receiver of the message; unless, the said 
sentence implies another meaning known to both the sender and the receiver of the text. Apparent in code [\#SM\&CS28] is the misappropriate use of the semantically related lexes "fall" and "throw" in Philippines context and perchance to other countries with English as second language (L2). The sender of the text used the word "fall" instead of "throw" to complete the communication process. In fact, these verbs both imply a command action to be done by the receiver of the message. The chief reason for this linguistic occurrence is the inability of the speaker to determine their appropriate grammatical usage and functions to come-up with appropriate sentences. Low vocabulary power could also one of the reasons of malapropism in the above case. In like manner, the discourse line [Sir... our principal is revolving around the corridor now.] with assigned code [\#SM\&CS29] likewise shows a clear occurrence of malapropism committed by the high school millennial students as shared by their respective teachers. As noted, sender of the message used the word "revolving" in lieu of the accurate word "walking". Possibly, the speaker somehow was able to send the message and was construed by the teacher as the receiver of the message. This could be so since the parts of speech [noun] as used in the above conversation is the same insofar as the exact word is concerned; hence, meaning was still established. In the long run, in code [\#SM\&CS30], the word "airforce" in the request sentence "Hello... please open window-let the airforce come in." was interchangeably used with simply "air" to come-up with an accurate sentence. The reason for this could also be phonological in nature anew. Social media are interactive computer-mediated technologies that facilitate the creation and sharing of information, ideas, career interests and other forms of expression via virtual communities and networks. The variety of stand-alone and built-in social media services currently available introduces challenges of definition; however, there are some common features: (i) social media are interactive Web 2.0 Internet-based applications; (ii) user-generated content, such as text posts or comments, digital photos or videos, and data generated through all online interactions, is the lifeblood of social media; and, (iii) users create service-specific profiles and identities for the website or app that are designed and maintained by the social media organization. Social media facilitate the development of online social networks by connecting a user's profile with those of other individuals or groups (Obar et. al., 2015, and Ellison 2007). 


\section{Figure 1: Malapropism on Social Media}

A

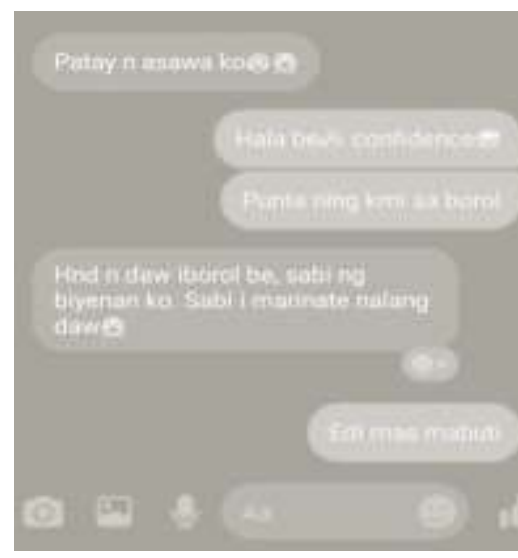

B

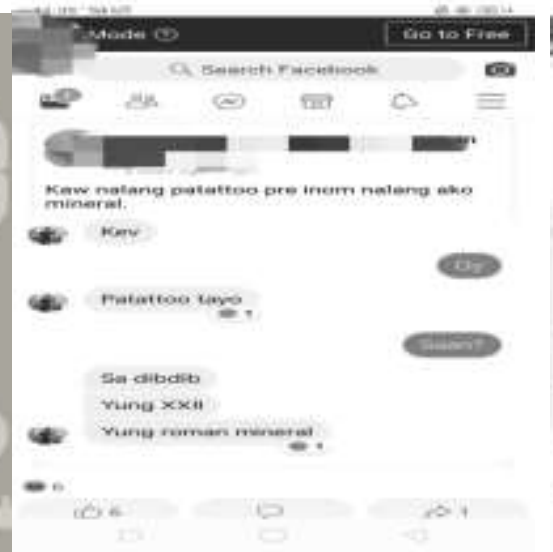

C

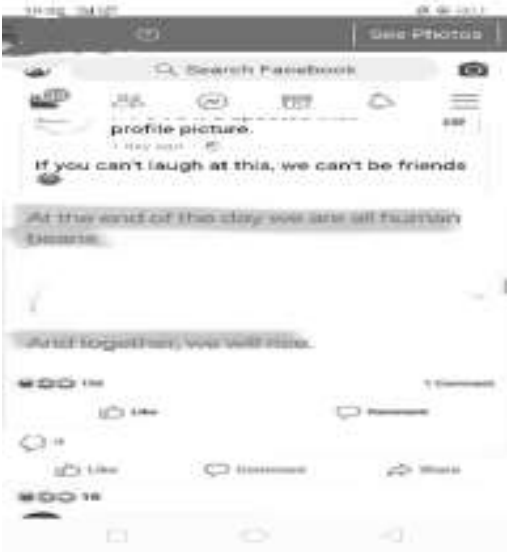

Source: Ben P. Lacay, High School English Teacher (October 17, 2019)

As for figure 1.B, the dialogue starts with "Ikaw na lang pa tattoo pre, inom na lang ako ng mineral" translated as [You better be the one trying the tattoo buddy, I'd rather drink a mineral water]. This is followed-up by a sentence in Filipino " $\mathrm{Pa}$ tattoo tayo pre". The receiver of information replied also in Filipino "Saan" equivalent to [where] in English. The sender then said " Sa dibdib, yong XXII, yong roman mineral" translated as [Near the chest, the XXII, the roman numerals]. Dichotomizing the conversation obviously implies that the word mineral was used to mean numerals. The sender of text may be was not able to recall the right word; hence, opted to use erroneously mineral to complete the sequence of communication. Relative to the last figure (1.C), the sentence [At the end of the day, we are human beans] has likewise been a manifestation of malapropism occurrence on social media. Beans was obviously used mistakenly instead of beings which sounded similarly with the former lexis.

\section{DISCUSSION}

As accentuated by Gumperz (1982), Poplack et. al., (1982), and Muysken (1995), code-switching still has semantic features in conveying messages. Communication is still possible despite the noted errors in the delivery of the message. In malapropism also, on account of its negative image and comical value, the sender of information is still able to deliver what is supposed to be conveyed. Hence, it is but proper to emphasize that these linguistic phenomena should unveil its positive aspect for the sake of communication. The goal must always be the understanding of the text and errors along the channels of communication must have been deemed negligible and trivial. It should open the door of acceptance and reverence due to cultural differences and linguistic typologies. Taking into account the results and conclusion, teachers must be aware of these linguistic episodes to be able to cope with these 
phenomena accordingly. To the extent that there is complete communication cycle in malapropism and code-switching occurrences, this could be used as a bridge to learn the L2. Since there has also been language assimilation in code-switching, this can be used as an avenue to master the second language by guiding learners toward fluency and accuracy of the target language. Learning of structure will just follow through series of drills and good practice. Moreover, as underscored by Phillipson (1992), Pennycook (1998), Calvet (1987), Spencer (1995), Holm (1989), and Mufwene (1997), the spread of English language was due to cultural and economic activities of the colonizers. Moreover, they likewise conjectured that the colonial discourse around English and English culture may have been employed to justify colonial and imperial economic activities, but these conversational about superiority of the former and the inferiority of the latter are not mere reflexes of the material domain. These could have been manifestations of cultural discourse itself. The present paper confirms the undeniable fact that the spread of English language in the Philippines is chiefly due to American colonization. It continues to thrive even up to the present digital era. In fact, English language created a status symbol putting a demarcation line between English-proficient and non-proficient Filipinos. The practice of code-switching [ Filipino to English generally] is a manifestation of cultural and linguistic hegemony. English speaking Filipinos still earn the top spot whether it be in media, entertainment, politics and education. In the long run, this paper also highlights that, historically, Spanish regime also contributed to the linguistic typology of the Philippines. The discourse lines [table 4] on broadcast media in particular are indicative of linguistic dominion by the Spaniards in the Philippines. Spanish language is still found on some educational materials and literary plays of the Philippines to date.

\section{CONCLUSION}
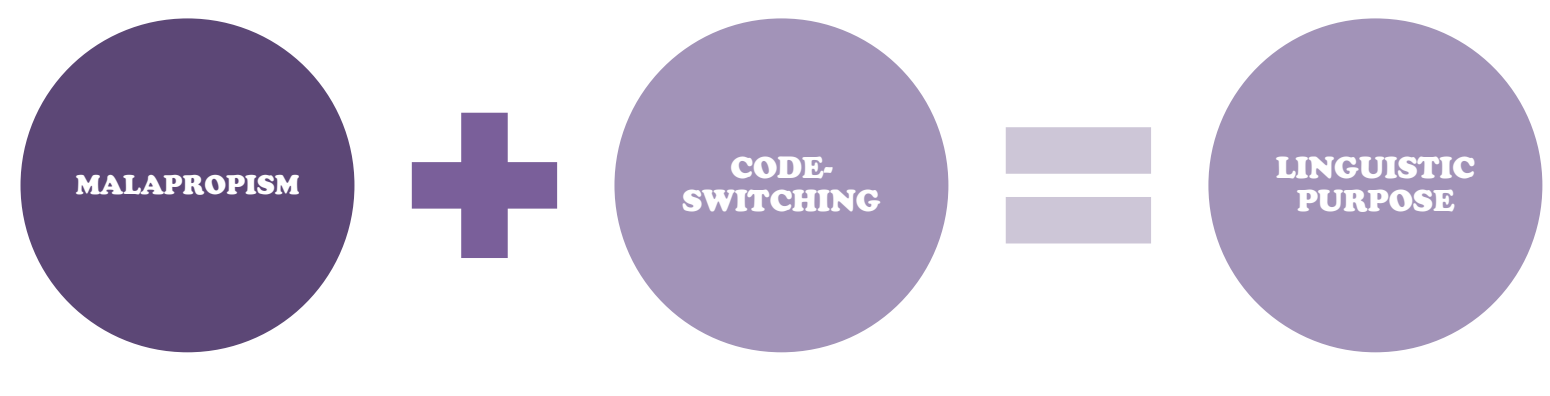

Figure 2 Interplay of Malapropism and Code-switching 


\section{Michael L. Estremera}

The studies conducted by Gumperz (1982), Poplack et. al., (1982), and Muysken (1995) primarily delved on the lexical and semantic effect of code-switching in discourse. On the other hand, Fay (1982), Zwisly (1982), and Aitchinson (2012) investigated on the phonological aspect of malapropism occurrence. It is, therefore, worthy to note that the foregoing scholars explored code-switching and malapropism in the context of monolingualism. This could imply that they conducted investigations of such phenomena in an English- speaking country with English as the language of the majority. None of these linguists scrutinized the occurrence of malapropism and code-switching in a multilingual milieu simultaneously. This research vacuum was filled-in the by the current research venture. Thus, figure 2 , delineates the interplay of malapropism and code-switching in the Philippines context to complete the communication process. Based on the previous discussion, the present author arrived at a conclusion that malapropism occurs in the Philippines coupled with code-switching linguistic phenomenon, as most of the malapropism episodes transpired are indeed prerequisites to shifting from one code to another. These linguistic episodes have veiled linguistic purposes which are manifested by the semantic elements of the dialogues. As a whole, the cultural influence dented by the colonizers like American and Spanish has been found to be chief contributory factor to the preceding linguistic phenomena. Filipinos try to be bilingual or even multilingual both in spoken and in written ways where errors are likely to happen. The inability to choose or low cache of vocabulary words could slightly be one of the reasons behind the phenomena. Carefully scrutinizing the above inferences led to the formulation of the language theory relative to interplay of code-switching and malapropism occurrence in multilingual countries called Multilingualism Error Theory. Philippines has rich linguistic typologies with over a hundred languages and dialectal variations apart from English as a second language (L2) of the Filipinos. The exposure of the interlocutors to multifarious variations of languages is the paramount reason for such phenomena. Speakers tend to barrow, insert, transcode, and invent new lexes either accidentally or intentionally; thus, occurrence of malapropism and code-switching inevitably transpire. As they converse, error in pronunciation and morphology are at times risked. However, these errors do not hamper the communication cycle. Both the sender and the receiver of the message reach the common point of discourse. This theory also explains that errors committed by multilingual speakers in the process of communication are subject to second thought. This means that offenders of malapropism and code-switching could also be aware of the appropriate word to insert; however, there may be some factors behind the commission of errors such as inhibition, internal and external disturbances, personal reasons, stockpile of lexical terms, phonological and morphological differences and similarities of the languages being used in discourses. The sophistication brought by code-switching and the entertainment value of social malapropism in the research locale, in particular, could also be one of the many factors. 
Linguistic Purpose and Historical Implications of Malapropism and Code-Switching

\section{REFERENCES}

Brice, A.E. (2015). "Multilingual Language Development". International Encyclopedia of the Social \& Behavioral Sciences. 2: 57-64. doi:10.1016/B978-0-08-097086-8.23126-7. ISBN 9780080970875. Retrieved from https://cutt.ly/4edpaUZ. October 17, 2019.

Calvet, Louis-Jean. (1987). La guerre des langues et les politiques linguistiques, Paris: Payot. (English version: Language wars and linguistic politics. tr. by Michel Petheram. Oxford and New York: Oxford University Press, 1998.)

Corbin, J. \& Strauss, A. (2008). Basics of qualitative research: Techniques and procedures for developing grounded theory (3rd ed.). Thousand Oaks, CA: Sage.

Cromdal, Jakob (2001). "Overlap in Bilingual Play: Some Implications of CodeSwitching for

Febiyaska, E. A., Ardi, P. (2019). Indonesian-English Code-Switching in Gogirl! Magazine: Types and Features. JELTL (Journal of English Language Teaching and Linguistics). e-ISSN: 2502-6062, p-ISSN: 2503-1848, Vol. 4(3) www.jeltl.org.

Fay, David; Cutler, Anne (1977). "Malapropisms and the Structure of the Mental Lexicon". Linguistic Inquiry. 8 (3): 505-520. JSTOR 4177997. Retrieved from https://cutt.ly/eedpLX9. October 17, 2019.

Gumperz, J. (1982). Discourse Strategies. Cambridge: Cambridge University Press.

John, Holm (1989). Pidgins and creoles. Volume II. Reference survey. Cambridge: Cambridge University Press, 1989. Pp. xxv $+445,11$ maps. Retrieved from https://bit.ly/3lg0pO3. March 12, 2021.

Liu, Jingxia (2010). Teachers' Code-Switching to the L1 in EFL Classroom. The Open Applied Linguistics Journal, 2010, 3, 10-23.

Mint \& Price (1992). The Miracle of Creolization: A Retrospective. New West Indian Guide, volume 75 number 1 \& 2 (2001): 35-64. Retrieved from https://bit.ly/3cmXeA5. March 12, 2021.

Mufwene, S.S., (2015). Pidgin and Creole Languages. International Encyclopedia of the Social \& Behavioral Sciences,2nd edition, Vol 18. Oxford: Elsevier. pp. 133-145.ISBN: 9780080970868. Retrieved from

Mujiono, Poedjosoedarmo, S., Subroto, E., \& Wiratno, T. (2013). Code switching in English as foreign language instruction practiced by the English lecturers at universities. International Journal of Linguistics, 5(2), 46.

Muhleisen, Susanne (2010). Heterogeneity in Word-Formation Patterns. John Benjamins Publishing Company, 2010. ISBN: 978--90-272-0585-8, Prix: $95 €$, 245 pages. https://doi.org/10.4000/lexis.1791.

Mukti, Prabowo, W. T \& Ena, T. O. (2018). The Use of Code Switching in General English Classes for Non-English Department Students in Indonesia. Indonesian Journal of EFL and Linguistics. Vol. 3 No. 2, eISSN: 2503-4197, pISSN: $2527-$ 5070 www. indonesian-efl-journal.org.

Indonesian Journal of EFL and Linguistics, 6(1), 2021 
Muysken, Pieter (1995). "Code-switching and grammatical theory". In L. Milroy; P. Muysken (eds.). One Speaker, Two Languages: Cross-disciplinary Perspectives on Code-switching. Cambridge: Cambridge University Press. pp. 177-98. Retrieved from https://cutt.ly/iedyHOj. October 21, 2019.

Lawrence A Palinkas, L. A., Horwitz, S. M., Green C. A., Wisdom J. P. (2013). Purposeful Sampling for Qualitative Data Collection and Analysis in Mixed Method Implementation Research. Administration and Policy in Mental Health and Mental Health Services Research 42(5). DOI: 10.1007/s10488-013-0528-y.

Pennycook (1998). English and the Discourses of Colonialism. London: Routledge. ISBN: 0-415-17847-9 (hardback); 0-415-17848-7 (paperback). pp.256. https://doi.org/10.1177\%2F13670069010050010702.

Phillipson, C. (1982) Capitalism and the Construction of Old Age. London: Macmillan. Retrieved from https://bit.ly/30CY85X. March 12, 2021.

Poplack, Shana; David Sankoff (1982). "Borrowing: the synchrony of integration". Linguistics. 22 (269): 99-136. doi:10.1515/ling.1984.22.1.99. hdl:10315/2840.

Sheridan, Richard Brinsley (2008). The Rivals: A Comedy, retrieved2012-0710"Quotations from Richard Brinsley Sheridan". Poem Hunter. Retrieved 201207-10. There are not alligators on the banks of the Nile, although there are crocodiles. Retrieved from https://cutt.ly/Redp0G4. October 17, 2019.

Spencer, S. G. (1995). Technical note: Video-based three-dimensional morphometrics. American Journal of Physical Anthropology 96:443-453. https://doi.org/10.1002/ajpa.1330960409.

Treffers, J. (2009). Language Dominance and Lexical Diversity: How Bilinguals and L2 Learners Differ in their Knowledge and Use of French Lexical and Functional Items. University of Reading. Retrieved from https://bit.ly/3rSjiJD. March 12, 2021.

Zwicky, Arnold (1982). "Classical malapropisms and the creation of the mental lexicon". In Loraine Obler and Lise Menn (ed.). Exceptional Language and Linguistics(PDF). Academic Press. pp. 115-132. ISBN 978-0-12-523680-5. Retrieved 2013-09-12. Retrieved from https://cutt.ly/IedpX6B. October 17, 2019.

\section{Acknowledgement}

The author is thankful to his Professor Dr. Shrill Asis-Gilbas of Sorsogon State University for the input shared which made this masterpiece possible. Her expertise in the field of language and linguistics is truly amazing.

\section{Conflict of Interest}

None 